Selected Papers from the 23rd International Radiocarbon Conference, Trondheim, Norway, 17-22 June, 2018 (C) 2019 by the Arizona Board of Regents on behalf of the University of Arizona. This is an Open Access article, distributed under the terms of the Creative Commons Attribution licence (http://creativecommons. org/licenses/by/4.0/), which permits unrestricted re-use, distribution, and reproduction in any medium, provided the original work is properly cited.

\title{
NEW RADIOCARBON-BASED ASSESSMENT SUPPORTS THE PROMINENCE OF TEL LACHISH DURING LATE BRONZE AGE IB-IIA
}

\author{
Lyndelle Webster ${ }^{1,2 *}$ (D) Katharina Streit ${ }^{3} \cdot$ Michael Dee $^{4} \cdot$ Irka Hajdas $^{5}$ (D) Felix Höflmayer $^{1}$ \\ ${ }^{1}$ Institute for Oriental and European Archaeology, Austrian Academy of Sciences, Hollandstraße 11-13, Vienna 1020, \\ Austria \\ ${ }^{2}$ Department of Ancient History, Macquarie University, NSW 2109, Australia \\ ${ }^{3}$ Institute of Archaeology, The Hebrew University, Mount Scopus, Jerusalem 91905, Israel \\ ${ }^{4}$ Centre for Isotope Research, University of Groningen, Nijenborgh 4, 9747AG Groningen, Netherlands \\ ${ }^{5}$ Laboratory of Ion Beam Physics, ETH Zurich, HPK H27, Otto-Stern-Weg 5, CH-8093 Zürich, Switzerland
}

\begin{abstract}
This article presents a new suite of radiocarbon $\left({ }^{14} \mathrm{C}\right)$ dates for the lower portion of the Late Bronze Age (LBA) sequence of Area S, Tel Lachish. The results show that the lowest levels reached by Ussishkin in the 1980s (S-2 and S-3) date significantly earlier than was previously thought. Level S-3, with its monumental architecture, belongs in the 2 nd half of the 15 th century BCE, as does the commencement of Level S-2. The laminated deposit of S- 2 continues through the first half of the 14th century BCE, coinciding at least in part with the Amarna period. This redating leads to improved agreement between archaeological and textual evidence regarding the presence of a substantial, prominent settlement at Lachish during LB IB-IIA, from the reign of Thutmoses III through the Amarna period.
\end{abstract}

KEYWORDS: Late Bronze Age chronology, radiocarbon dating, Shephelah, Tel Lachish.

\section{INTRODUCTION}

Textual sources concerning the southern Levant in the 15th-14th centuries BCE give a picture of Canaanite rulers interacting with the Egyptian administration. The clearest window we have on this relationship comes from the Amarna Letters of the 14th century BCE (Moran 1992; Rainey 2015), yet also in the second half of the 15th century BCE-widely considered the formative years of an Egyptian administration in the region-comes similar correspondence, particularly within the Ta'anach corpus (Horowitz et al. 2006:127-151). ${ }^{1,2}$ Further evidence of power centers in the earlier Late Bronze Age (LBA) southern Levant, as seen by the Egyptians, is provided by the administrative text of Papyrus Hermitage $1116 \mathrm{~A}$ verso (Golénischeff 1913). Dated to the reign of Amenhotep II (Redford 1965:107-110), it mentions Maryannu (chariot warrior aristocracy) envoys on their way to Egypt, stopping at various key towns. Appearing on the same document, though not within the list of towns, is the provisioning at Thebes of an envoy from Lachish (Epstein 1963; Helck 1971).

From the textual evidence one would reasonably expect to find convincing Late Bronze IB-IIA settlement remains at key southern Levantine tell sites. ${ }^{4}$ Yet there is uneasiness between the archaeological and textual evidence; some towns whose rulers figure prominently in correspondence, exhibit a surprising paucity or lack of settlement evidence. Many scholars

\footnotetext{
*Corresponding author. Email: lyndelle.webster@oeaw.ac.at

${ }^{1}$ The historical chronology of New Kingdom Egypt is secure, and supported by radiocarbon dating (Bronk Ramsey et al. 2010; Dee 2013b); consequently reigns and absolute chronology are used interchangeably here.

${ }^{2}$ Ta'anach Letters no. 5-6 are of particular interest, addressed to the prince of Ta'anach by a certain Amenhotep-an Egyptian official, or perhaps Amenhotep II (e.g. Albright 1944; Malamat 1961).

${ }^{3}$ The accession of Amenhotep II is dated 1446-1421 (95\% probability; Dee 2013b, NKM1 with reign lengths in Shaw 2000).

${ }^{4}$ The terms LB IB and IIA were defined with reference to Egyptian chronology, though they refer to the pottery characterizing these timeframes. With minor variation, LB IB is taken from the campaign of Thutmoses III to the ascension of Amenhotep III; LB IIA covers the so-called Amarna period and the last kings of the 18th dynasty, circa 1300 BCE (e.g. Martin 2011:20; Panitz-Cohen 2014:542).
} 
have commented on the poor LB IIA remains corresponding to the Amarna era (e.g. Goren et al. 2004:321; Ussishkin 2004a:74-75; Na'aman 2011). While the long occupation gaps for LB I have reduced with ongoing excavation and ceramic analysis, some sites that figure in 15th century BCE written sources have puzzling LB IB occupation gaps (e.g. Ussishkin 2004a:58). Resolution of these issues is no simple matter; however, as shown in this article for the case of Tel Lachish, imprecision in the absolute dating of strata is a contributing factor.

\section{TEL LACHISH}

Tell ed-Duweir ${ }^{5}$ - whose identification as ancient Lachish is well-established-is one of the main type-sites for the LBA in south-central Israel (Figure 1). A large site for this region ( 7 ha at the summit, 12 ha at the base), it guards a fertile valley connecting the coastal plain in the west with the highlands to the east. Lachish is regarded as one of the three dominant city-states of the Shephelah during the Late Bronze Age (Finkelstein 1996; Na'aman 1997, 2011); the town and/or its rulers appear in eight Amarna Letters, of which five are addressed from a ruler of Lachish to the king of Egypt (EA 328-332; Moran 1992: Rainey 2015). ${ }^{6}$ Remains dating to the LBA-predominantly LB II-III-have been uncovered in many locations on the mound (Figure 1), as well as nearby caves and tombs. ${ }^{7}$ The remains have been prominent in discussions of the period, and furnished evidence for Egyptian influence and involvement in the region. ${ }^{8}$

Tel Lachish has been excavated by six excavation teams. ${ }^{9}$ Of most importance to this article are (1) the British excavations in the 1930s-uncovering the Fosse Temple; (2) the major excavations led by David Ussishkin in the 1970s-1990s-establishing the LBA stratigraphy in the deep trench of Area S; and (3) the current Austrian-Israeli excavations from which radiocarbon data is reported. ${ }^{10}$

The 2013-2017 expedition by Garfinkel, Hasel, and Klingbeil in the northeastern part of the mound added to our knowledge of later LBA levels as well as the destruction that brought Middle Bronze Age (MBA) Lachish to an end (Sass et al. 2015; Weissbein et al. 2016; Garfinkel et al. 2019a, 2019b). However, they did not expose occupation remains from the rather elusive LB I-IIA period. ${ }^{11}$

The Austrian-Israeli excavations commenced in 2017, following the cessation of work by Garfinkel, Hasel, and Klingbeil. The new expedition currently focuses on the later Middle Bronze through early Late Bronze Age strata and re-examining their chronology with highresolution AMS ${ }^{14} \mathrm{C}$ dating. To this end, Ussishkin's Area $\mathrm{S}$ has been reopened, continuing the excavation of earlier LBA levels; as of 2018 work in Area P has also been renewed (Streit et al. 2018).

\footnotetext{
${ }^{5}$ Local Arabic name; ITM/NIG grid reference 185660, 608200.

${ }^{6}$ Letters from rulers of Lachish may also include EA 311 (Goren et al. 2004:289) and EA 294 (Rainey 2015:1134-1137, 1599-1600, but see Goren et al. 2004:294).

${ }^{7}$ Excavation reports: Tufnell et al. (1940); Tufnell (1958); Barkay and Ussishkin (2004); Ussishkin (2004c, 2004d, 2004e).

${ }^{8}$ For recent discussion of Lachish and Levantine-Egyptian relations, see Koch (2017), Sala and Tucci (2019), and Streit (2019).

${ }^{9}$ Expeditions: Starkey, 1932-1938; Aharoni, 1966-1968; Ussishkin, 1973-1994; Garfinkel, Hasel and Klingbeil, 2013-2017; Ganor, 2016; Höflmayer and Streit, 2017-current.

${ }^{10}$ The Austrian-Israeli excavation is directed by Felix Höflmayer and Katharina Streit under the auspices of the Institute of Oriental and European Archaeology (OREA) at the Austrian Academy of Sciences (ÖAW), together with the Institute of Archaeology at the Hebrew University of Jerusalem and the University of Vienna.

${ }^{11}$ Personal communication, Yosef Garfinkel.
} 

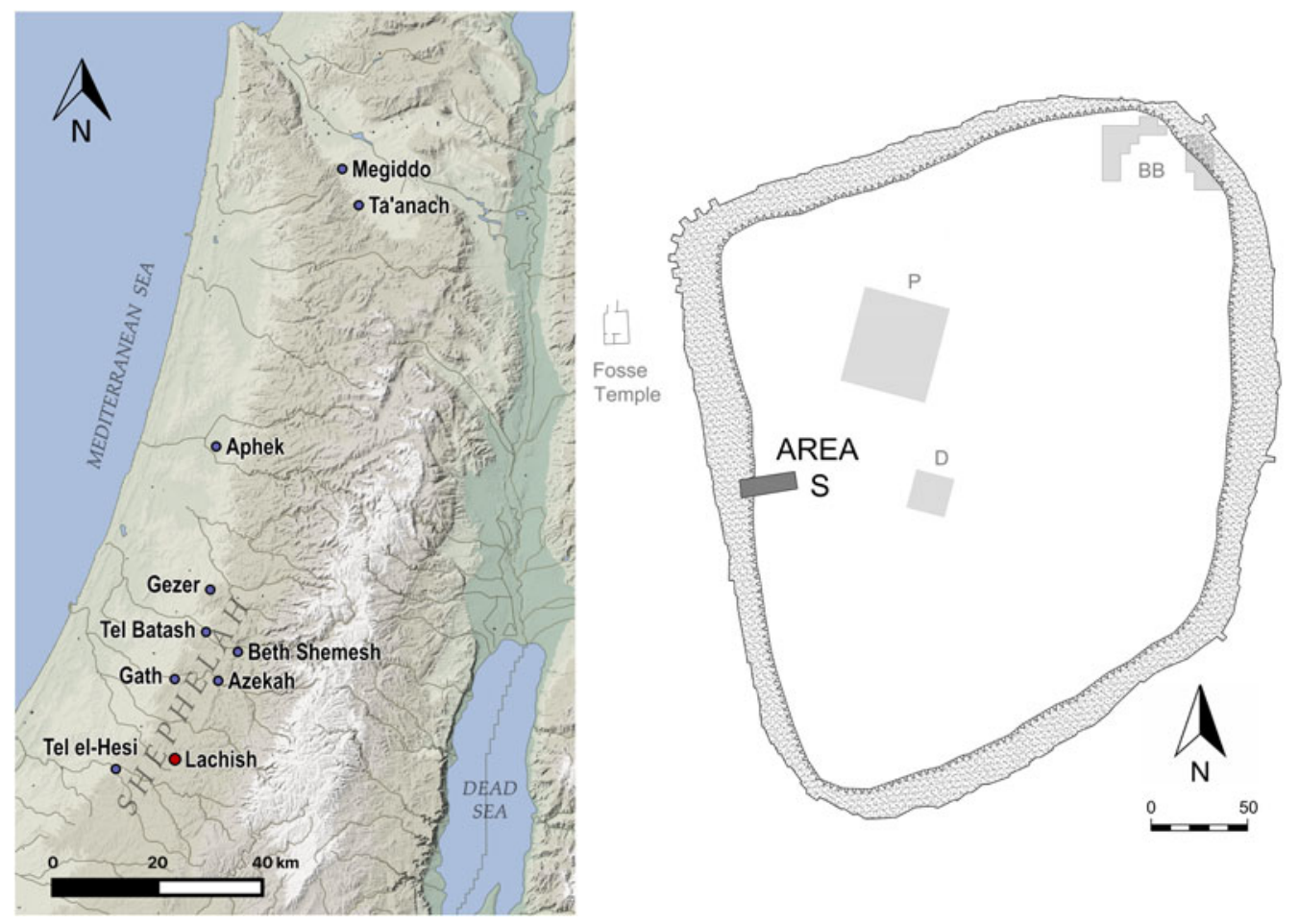

Figure 1 (Left) Tel Lachish among LBA Shephelah sites, and others mentioned in the text; (right) site plan of Tel Lachish showing the main locations where Late Bronze Age remains have been exposed, and highlighting the position of Area S (based on Ussishkin 2004b: Fig. 2.9-10; Weissbein et al. 2016; Garfinkel et al. 2019a).

\section{Lachish Stratigraphy: LB I-IIA}

The sole substantial evidence for continuous activity at Tel Lachish through LB IB-IIA is the Fosse Temple, so-called because of its construction within the disused Middle Bronze moat at the base of the mound (Figure 1). Its three phases, spanning LB IB to LB IIB, were fully excavated and dismantled by Starkey's 1930s excavation (Tufnell et al. 1940). The Fosse Temple is well-known for rich finds attesting to strong international connections, particularly with Egypt. Surprisingly, evidence for settlement on the mound contemporary with Fosse Temple I, and the founding of Fosse Temple II, has been elusive despite considerable exploration.

In Area $\mathrm{P}$ on the summit, very little was identified stratigraphically between the domestic remains of Level P-2 (dated to the late LB IIA) and the last use of the Middle Bronze palace structure (Level P-3). Only a few pits and a possible surface were attributed to LB IA, along with several pits in the vicinity of the Fosse Temple (Singer-Avitz 2004a:1021; 2004b:1026; Ussishkin 2004a:57-58, 2004c). Within the LBA cemeteries of Lachish, just five tombs are safely attributable to the LB I (Singer-Avitz 2004a:1021). On the basis of this evidence, a sparse settlement was suggested for LB IA, and a period of abandonment during LB IB.

No architectural remains on the mound are attributed to the Amarna period (Ussishkin 2004a:59-60). The resettlement of Area P (P-2) after LB I was dated to the late LB IIA (Clamer 2004:1182-1184), along with the lowest levels of Area S (Yannai 2004:1061-1062). 
Nevertheless a settlement gap during the Amarna period was not entertained, and it was thought that this level/s had not been reached when excavations ceased in the deep Area $\mathrm{S}$ trench. This was the understanding with which we recommenced work in 2017.

The lack of settlement evidence on the mound for LB IB-IIA does not sit well with Papyrus Hermitage 1116A (and letters of late 15th century BCE), nor with the Amarna letters. Further, it has left a question mark over who Fosse Temple I and II served. ${ }^{12}$

\section{Radiocarbon Dating of LB I-IIA Strata at Lachish}

An important task upon recommencement of work in Area $\mathrm{S}$ has been to re-examine, with high-resolution AMS dating, the absolute chronology of the previously identified LBA levels. Particularly crucial to connecting the old and new excavations, are dates for the lowest levels (S-2 and S-3), from whence a sequence spanning the early LBA to MBA may be expanded as excavation continues. The purpose of this article is to present the revised radiocarbon-based dating of S-2 and S-3, along with a brief discussion of implications for interpreting the occupation history of this very important site.

A set of ${ }^{14} \mathrm{C}$ dates from Area $\mathrm{S}$ was published by Carmi and Ussishkin (2004). Whilst this sequence was ground-breaking for its time, it had little impact on the dating of strata due to limitations of that time: (1) Bayesian modeling of radiocarbon data was not yet widely used; (2) samples were primarily from bulk wood charcoal, due to the use of decay counting methods; and (3) precision was lower than can now be attained. Bayesian modeling has drawn out valuable chronological information from this dataset, particularly for later LBA levels (refer to Webster et al. 2018), however the lower levels of Area S remained particularly weak-an issue that is now addressed by the new, precise AMS data reported here.

It should be noted that while ${ }^{14} \mathrm{C}$ data for later LBA strata (i.e. Levels VII and VI) is available from other parts of the mound-Areas P and GE (Carmi and Ussishkin 2004) and more recently the northeastern part of the mound (Garfinkel et al. 2019a)_radiocarbon data for earlier LBA strata is thus far restricted to Area S.

\section{Late Bronze Age Stratigraphy of Area S}

Five main LBA phases were uncovered in Area S (Table 1; Barkay and Ussishkin 2004). The upper levels, VI and VII, represent prosperous cities that both ended in destruction, providing important 13th and 12th centuries BCE ceramic assemblages. Below the two subphases of Level VII $(a, b)$, were the meagre remains of Level S-1 domestic architecture, consisting of just a few wall segments and patches of flooring. These remains were laid directly upon the laminated deposit of Level S-2. Found extending across most of Area S, Level S-2 consisted of a thick build-up of alternating clay and dark brown layers, the latter being rich in ash and carbonized organic remains. The overall thickness varied across the area $(0.5-1.6 \mathrm{~m})$, as did the number of layers (from just a few to a dozen). The layers were horizontal in many excavation squares, but in places they rise and fall, having been deposited over the decayed mudbrick courses of earlier walls (e.g. Ussishkin W1077/1075) and compressed by later architecture. No architecture was found in association with S-2. Laminated features similar to Level S-2 have been noted at other sites, with some particularly striking examples (by depth and extent) encountered at Tel Gezer (Dever

\footnotetext{
${ }^{12}$ See, for example, Finkelstein (1988:343), Bietak (2002), Ussishkin (2004a:58-59).
} 
Table 1 Late Bronze Age stratigraphy of Lachish Area S (based on Ussishkin 2004a, Table 3.3; Barkay and Ussishkin 2004).

\begin{tabular}{|c|c|c|c|}
\hline Phase $^{13}$ & Cultural period $^{14}$ & Description & $\begin{array}{l}\text { Contemporary } \\
\text { strata in other } \\
\text { areas }\end{array}$ \\
\hline VI & LB III / IA IA & $\begin{array}{l}\text { Monumental, pillared building, } \\
\text { destroyed by fire. }\end{array}$ & $\begin{array}{l}\text { Area P Level VI } \\
\text { Temple }\end{array}$ \\
\hline VII & LB IIB & $\begin{array}{l}\text { Domestic architecture (VIIa,b). Level } \\
\text { VIIa destroyed by fire. }\end{array}$ & $\begin{array}{l}\text { Fosse Temple III; } \\
\text { P-1 }\end{array}$ \\
\hline S-1 & $\begin{array}{l}\text { Yannai (2004): } \\
\text { LB IIA, late 14th c. } \\
\text { BCE }\end{array}$ & $\begin{array}{l}\text { Floor and fragmentary walls, mainly } \\
\text { in the southern part of the area. } \\
\text { Overall architectural plan not clear. }\end{array}$ & $\begin{array}{l}\text { Later Fosse } \\
\text { Temple II; P-2 }\end{array}$ \\
\hline $\mathrm{S}-2$ & $\begin{array}{l}\text { Revision: } \\
\text { LB IB-LB IIA? } \\
\text { 2nd half } 15 \text { th } c . \text { to } \\
\text { 14th c. BCE }\end{array}$ & $\begin{array}{l}\text { Laminated feature with alternating } \\
\text { layers of clay and burnt organic } \\
\text { remains. Up to } 1.6 \mathrm{~m} \text { thick and with } \\
\text { sequences of up to } \sim 12 \text { burnt layers. }\end{array}$ & $\begin{array}{l}\text { Revision: } \\
\text { S-3 and early } S-2 \\
\text { contemporary } \\
\text { with Fosse }\end{array}$ \\
\hline$S-3$ & & $\begin{array}{l}\text { Monumental building } \\
\text { (Ussishkin W1077/1075); } \\
\text { abutted by two subphases of external } \\
\text { architecture (S-3b and S-3a). }\end{array}$ & Temple I? \\
\hline
\end{tabular}

1986:61-63; 73-76), Tel Aphek (Gadot 2009:96-98) and Tel Hesi (Petrie 1981, P1.III; Bliss 1894:64-65). On the nature of these deposits there is lack of agreement; explanations have included threshing floors, waste disposal areas, animal pens, industrial deposits or destruction layers. For a recent geoarchaeological assessment of a smaller deposit at Megiddo, see Shahack-Gross et al. (2013).

Immediately underneath the S-2 deposit was found the substantial architecture of Level S-3. This includes monumental walls_-Ussishkin's W1077 and W1075_forming part of a building that lies mostly beyond the northern extent of the area (Figure 2). Walls of several smaller external units abutting this structure on the south were exposed by Ussishkin across Area S. In 2017-2018 the renewed Austrian-Israeli excavation uncovered an earlier subphase of external architecture (S-3b) abutting W1077/W1075.

While Level S-3, with its monumental architecture, undoubtedly represents a well-organised settlement, the picture is less clear-cut for Level S-2. Since no associated architecture was found, one may question whether there was an associated settlement on the mound, or if the deposit merely reflects utilization of space during a period of abandonment. Two aspects point towards the former: Firstly, the S-2 deposit contains large quantities of pottery sherds, including many imports, along with animal bones and flint tools; as Barkay and Ussishkin (2004:342) argued, this best fits an open area adjacent to a settlement. Secondly, the new excavations have revealed similar charred layers sandwiched between or associated with S-3 architecture, suggesting that S-2 does not represent a completely new pattern of activity.

\footnotetext{
${ }^{13}$ Levels S-3 to S-1 carry local area designations, as they could not be connected into a unified site stratigraphy (Ussishkin 2004b: 43-44).

${ }^{14}$ Ussishkin (2004a:57) uses somewhat different designations for the Late Bronze Age divisions: LB II, LB IIIA, and LB IIIB in the excavation report equate to LB IIA, LB IIB, and LB III as used here.
} 


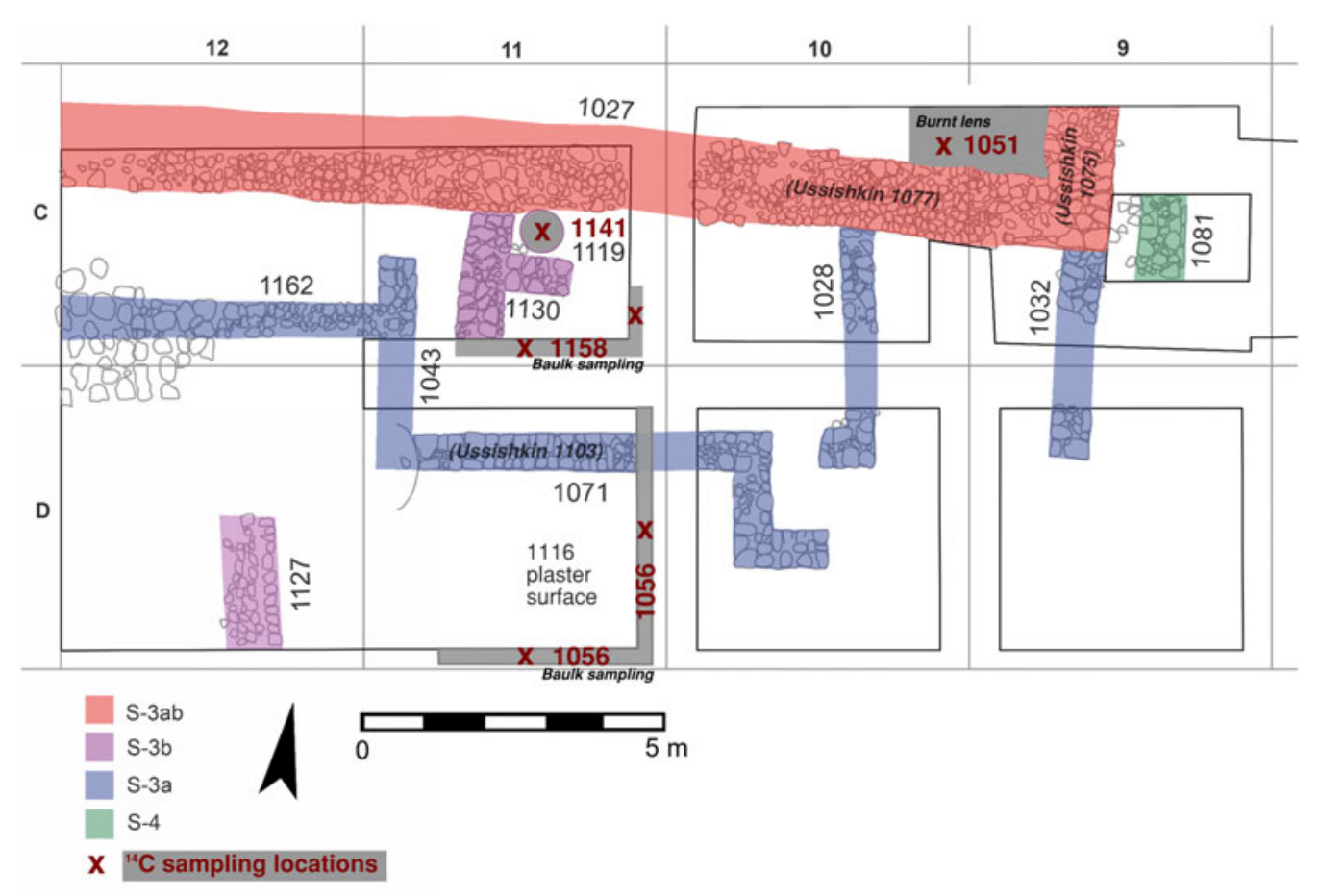

Figure 2 Plan of Level S-3 architecture, and the ${ }^{14} \mathrm{C}$ sampling locations of both S-3 and S-2.

Yannai (2004:1061-1062) considered the S-3-S-1 pottery assemblages to be chronologically indistinguishable, and noted similarity to the Fosse Temple II pottery. Fosse Temple II could not have commenced prior to the reign of Amenhotep III, ${ }^{15}$ since a plaque bearing this king's name was found below its foundations (Tufnell et al. 1940:69, 90, Pl. XXXIIA:5). A seal of Amenhotep III was also found in an S-2 context (Keel 2004, List no. 25). Yannai favoured a dating of both Fosse Temple II and S-3-S-1 after Amenhotep III, in the late 14th century BCE. Ussishkin (2004a:57-59) accepted Tufnell's date for the Fosse Temple II enlargement during the reign of Amenhotep III (Tufnell et al. 1940:20), but took S-3-S-1 as contemporaneous only with the later part of Fosse Temple II.

\section{${ }^{14} \mathrm{C}$ SAMPLING APPROACH}

The samples reported here were collected during the 2017-2018 seasons of the Austrian-Israeli excavation. All are short-lived-a variety of seed types collected from burnt contexts, rich in organic remains (Figures 2-4).

Upon reopening Area S, the previously excavated LBA levels were readily recognized: remains of S-3; the laminations of S-2, preserved in many baulks; and Levels VII and VI in the major northern and southern sections. Samples for Level S-3 were obtained both inside and outside the monumental building. Inside the building (close to the northern edge of the area) a seed-rich burnt lens (L1051; Figure 3) was found, clearly abutting the monumental walls (Ussishkin's

\footnotetext{
${ }^{15}$ The accession of Amenhotep III is dated 1409-1384 (95\% probability; Dee 2013b, NKM1 with reign lengths in Shaw 2000).
} 


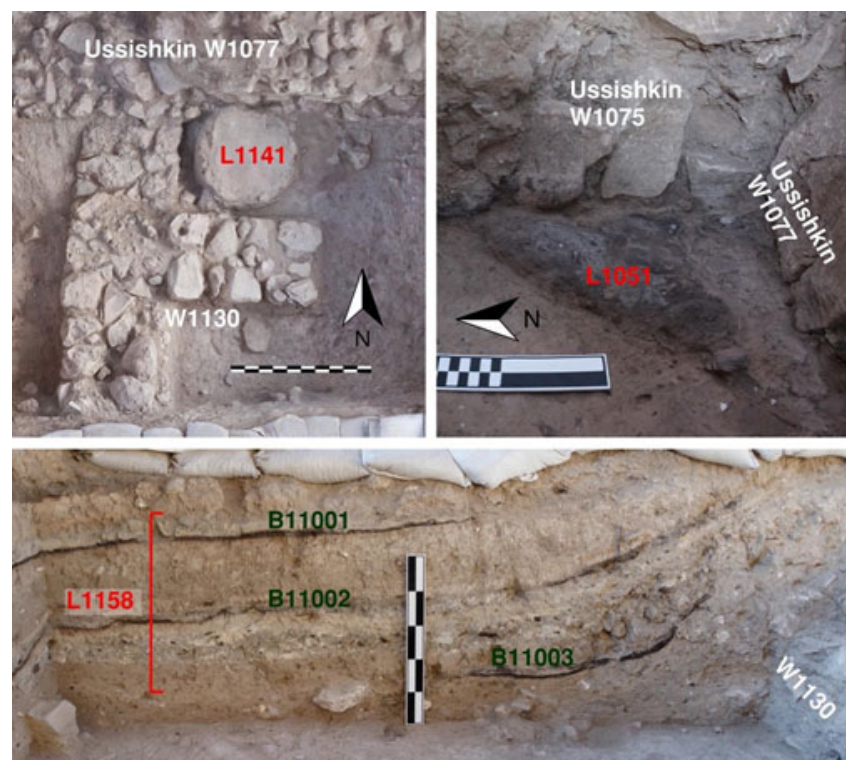

Figure 3 Level S-3 ${ }^{14} \mathrm{C}$ contexts: (top left) S-3b tabun L1141; (top right) detail of burnt lens L1051 within the monumental building, abutting Ussishkin's W1077/1075 (part of the deposit has been removed to show the underlying surface); (bottom) burnt lenses L1158 between S-3b and S-3a architecture (south baulk of square C11).

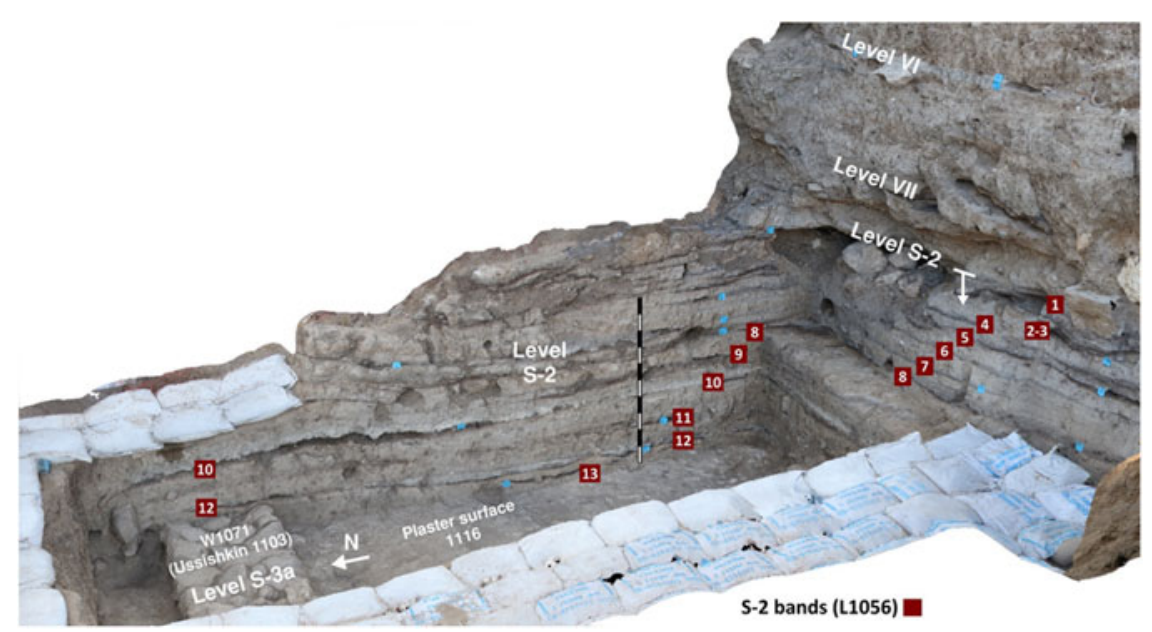

Figure 4 Level S-2 sequence of burnt lenses L1056, with sampling locations marked.

W1077/1075). This discovery is particularly important since no floor/surface was previously identified inside the monumental building. The S-3 external architecture is represented by samples from S3-b tabun L1141 and overlying burnt lenses L1158 (Figure 3). The uppermost S-3 sample consists of charred remains lying directly upon plaster surface L1116 (Figure 4). Barkay and Ussishkin (2004) considered L1116 the floor of Unit 8018 
(our S-3a subphase), though the present expedition recognizes that L1116 in fact ran underneath wall 1071 (Ussishkin's W1103) rather than abutting it.

The thick S-2 deposit overlies L1116 and W1071 in square D11 (Figure 4). This sampling location was chosen since here the full depth of S-2 could be sampled (including $\sim 12$ preserved layers) and subsequent occupation Levels VII and VI can be readily identified in the adjacent southern section. Further, square D11 is a focus of continued excavation to expose (and radiocarbon date) deeper strata. Rather than excavating down through standing baulks, collection of S-2 material was done directly from the eastern and southern sections of the square; this facilitated more precise and efficient sampling from the series of burnt lenses. Samples were collected from each clearly separated lens (see "band" numbers in Figure 4), though fewer were radiocarbon dated (Table 2).

\section{${ }^{14} \mathrm{C}$ LABORATORY METHODS}

Radiocarbon dating was carried out at the University of Groningen and ETH Zurich AMS laboratories. Only single entities (i.e. one seed or fragment) were prepared for each measurement, to avoid any possibility of averaging between seeds of differing age. An acidalkaline-acid (AAA) pretreatment protocol was generally applied to remove carbon-bearing contaminants (Mook and Streurman 1983); in some cases the alkaline wash was omitted to avoid dissolution of the samples (ETH-91523 to 91527). As shown by Wild et al. (2013), dating humic acids from such contexts yields reliable results. The pretreated samples were combusted in an elemental analyzer (EA), and the resultant $\mathrm{CO}_{2}$ converted to graphite using the $\mathrm{H}_{2} / \mathrm{Fe}$ method. An isotope ratio mass spectrometer (IRMS) coupled to the EA measured $\delta^{13} \mathrm{C}$ for isotopic fractionation correction. Accelerator mass spectrometry (AMS) radiocarbon analysis of the samples, along with standards and blanks, was made using a MICADAS (IonPlus ${ }^{\circledR}$ ) accelerator.

Radiocarbon ages are reported in ${ }^{14} \mathrm{C}$ years before present (BP) following international convention (Stuiver and Polach 1977; Millard 2014). Calibrated ages in calendar years were obtained using OxCal v 4.3.2 (Bronk Ramsey 2009a) and the IntCal13 calibration curve (Reimer et al. 2013) interpolated to yearly intervals (Resolution $=1$ ).

\section{RESULTS}

The new ${ }^{14} \mathrm{C}$ data for the lower levels of Area $\mathrm{S}$ form a coherent, well-ordered dataset in the range 15th to 13th centuries BCE (Table 2, Figure 5). ${ }^{16}$ Unfortunately, much of the S-2 data has considerable spread (both 1 and $2 \sigma>100$ years) due to a large wiggle in the calibration curve (see supplementary online materials Figure X1). To obtain more precise chronological information, the ${ }^{14} \mathrm{C}$ data should be combined with prior knowledge of stratigraphic order, usually done using a Bayesian approach (Buck et al. 1991, 1992; Bronk Ramsey 2009a). Such an analysis was first applied to the new data in isolation (Figure 6, Model A), before incorporating existing ${ }^{14} \mathrm{C}$ data from Area S (Carmi and Ussishkin 2004) (Figure 6, Model B). The OxCal code for both models is provided in the supplemental online materials.

\footnotetext{
$\overline{{ }^{16} \text { One date, GrM-111 }} 15$, is considered unreliable, not merely because it is an obvious outlier, but on the basis of very low target current noted for this sample during measurement. It is reported in Table 2, but not discussed further.
} 
Table 2 New radiocarbon dates obtained for the lowest levels of Area S, Tel Lachish.

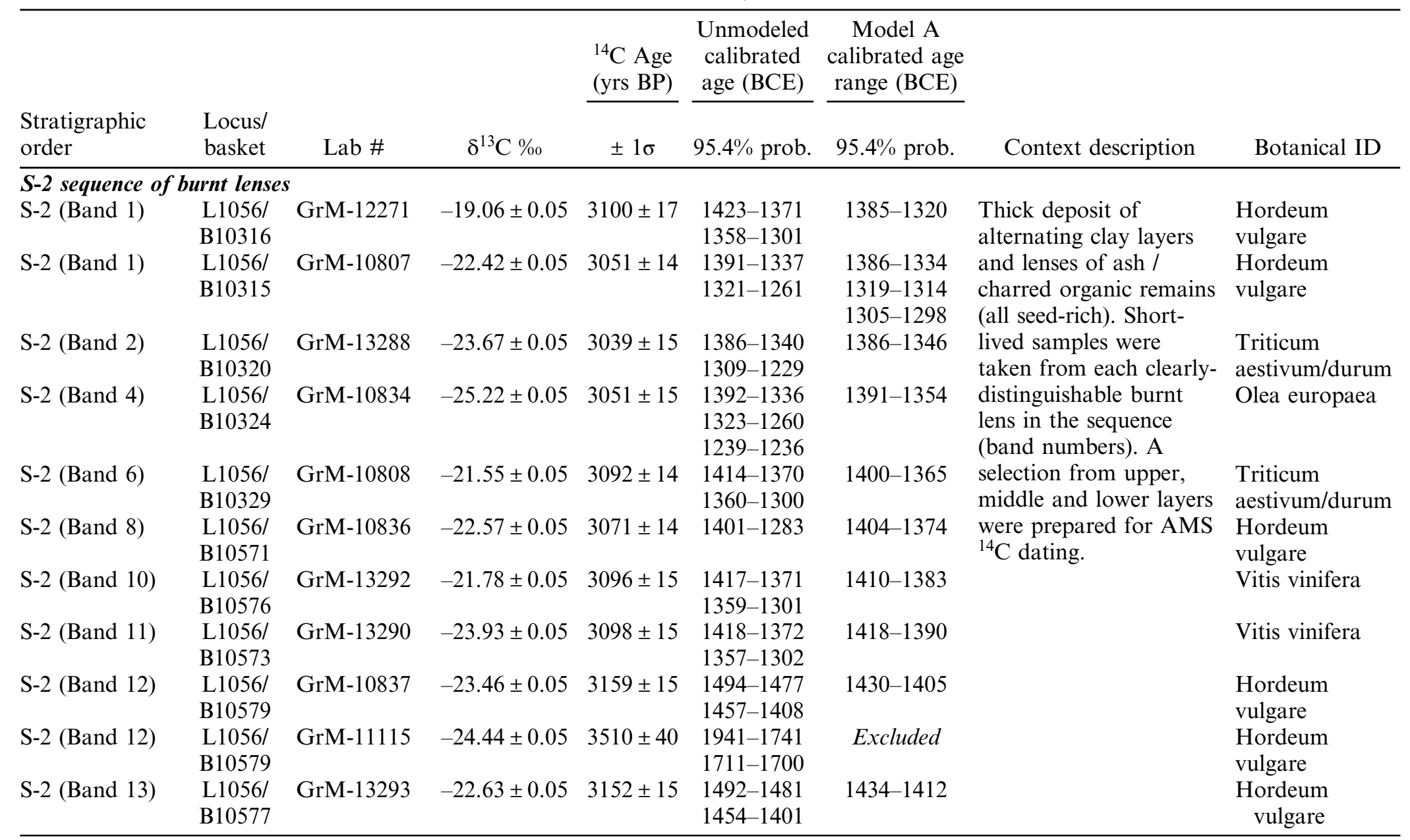


Table 2 (Continued)

\begin{tabular}{|c|c|c|c|c|c|c|c|c|}
\hline \multirow[b]{2}{*}{$\begin{array}{l}\text { Stratigraphic } \\
\text { order }\end{array}$} & \multirow[b]{2}{*}{$\begin{array}{l}\text { Locus/ } \\
\text { basket }\end{array}$} & \multirow[b]{2}{*}{ Lab \# } & \multirow[b]{2}{*}{$\delta^{13} \mathrm{C} \% 0$} & \multirow{2}{*}{$\begin{array}{l}{ }^{14} \mathrm{C} \text { Age } \\
(\mathrm{yrs} B \mathrm{~B}) \\
\pm 1 \sigma\end{array}$} & \multirow{2}{*}{$\begin{array}{c}\begin{array}{c}\text { Unmodeled } \\
\text { calibrated } \\
\text { age (BCE) }\end{array} \\
95.4 \% \text { prob. }\end{array}$} & \multirow{2}{*}{$\begin{array}{c}\text { Model A } \\
\text { calibrated age } \\
\text { range (BCE) } \\
95.4 \% \text { prob. }\end{array}$} & \multirow[b]{2}{*}{ Context description } & \multirow[b]{2}{*}{ Botanical ID } \\
\hline & & & & & & & & \\
\hline \multicolumn{9}{|c|}{ On $S$-3a surface (directly below $S-2$ samples) } \\
\hline S-3a & $\begin{array}{l}\text { L1056/ } \\
\text { B10657 }\end{array}$ & GrM-13922 & $-21.68 \pm 0.05$ & $3225 \pm 30$ & $\begin{array}{l}1607-1583 \\
1560-1553 \\
1546-1429\end{array}$ & $1440-1418$ & $\begin{array}{l}\text { Small patches of } \\
\text { charred organic remains } \\
\text { directly on plaster } \\
\text { surface L1116. }\end{array}$ & Triticum s.p. \\
\hline \multicolumn{9}{|c|}{ Burnt lenses between $S-3 a$ and $S-3 b$ architecture } \\
\hline S-3a-b (Band 1) & $\begin{array}{l}\text { L1158/ } \\
\text { B11001 }\end{array}$ & ETH-91523 & $-23.8 \pm 1$ & $3127 \pm 21$ & $\begin{array}{l}1445-1377 \\
1343-1306\end{array}$ & $1442-1421$ & \multirow{4}{*}{$\begin{array}{l}\text { Series of three lenses } \\
\text { rich in charred organic } \\
\text { remains and cereal } \\
\text { grains. Similar to S-2 } \\
\text { deposit. }\end{array}$} & \multirow{4}{*}{$\begin{array}{l}\text { Hordeum } \\
\text { vulgare } \\
\text { Hordeum } \\
\text { vulgare } \\
\text { Hordeum } \\
\text { vulgare }\end{array}$} \\
\hline S-3a-b (Band 2) & $\begin{array}{l}\text { L1158/ } \\
\text { B11002 }\end{array}$ & ETH-91524 & $-20.3 \pm 1$ & $3162 \pm 21$ & $1497-1408$ & $1444-1423$ & & \\
\hline S-3a-b (Band 3) & $\begin{array}{l}\text { L1158/ } \\
\text { B11003 }\end{array}$ & ETH-91525 & $-23.2 \pm 1$ & $3131 \pm 21$ & $\begin{array}{l}1449-1379 \\
1341-1307\end{array}$ & $1447-1426$ & & \\
\hline \multicolumn{7}{|l|}{ In $S-3 b$ tabun } & & \\
\hline \multirow[t]{2}{*}{ S-3b } & $\begin{array}{l}\text { L1141/ } \\
\text { B10986 }\end{array}$ & ETH-91527 & $-23.9 \pm 1$ & $3192 \pm 21$ & $1502-1426$ & $1456-1428$ & \multirow[t]{2}{*}{$\begin{array}{l}\text { Seeds sieved from ashy } \\
\text { tabun contents. }\end{array}$} & \multirow{2}{*}{$\begin{array}{l}\text { Hordeum } \\
\text { vulgare } \\
\text { Olea europaea }\end{array}$} \\
\hline & $\begin{array}{l}\text { L1141/ } \\
\text { B10992 }\end{array}$ & ETH-91526 & $-22.9 \pm 1$ & $3208 \pm 21$ & $1510-1430$ & $1457-1428$ & & \\
\hline \multicolumn{9}{|c|}{ Deposit inside monumental building (north of, and abutting, W107711075) } \\
\hline \multirow[t]{3}{*}{$\mathrm{S}-3$} & $\begin{array}{l}\text { L1051/ } \\
\text { B10356 }\end{array}$ & GrM-10838 & $-22.18 \pm 0.05$ & $3136 \pm 15$ & $\begin{array}{l}1444-1391 \\
1335-1324\end{array}$ & $1445-1420$ & \multirow{3}{*}{$\begin{array}{l}1-2 \mathrm{~cm} \text { lens of ash and } \\
\text { charred organic } \\
\text { remains, including } \\
\text { numerous cereal grains, } \\
\text { abutting the } \\
\text { monumental walls } \\
\text { W1077/1075 from the } \\
\text { inside of the structure. }\end{array}$} & Olea europaea \\
\hline & & GrM-10810 & $-22.28 \pm 0.05$ & $3173 \pm 14$ & $\begin{array}{l}1496-1472 \\
1464-1416\end{array}$ & $1450-1423$ & & $\begin{array}{l}\text { Triticum } \\
\text { dicoccum }\end{array}$ \\
\hline & & GrM-10809 & $-22.71 \pm 0.05$ & $3181 \pm 14$ & $1497-1425$ & $1452-1424$ & & $\begin{array}{l}\text { Hordeum } \\
\text { vulgare }\end{array}$ \\
\hline
\end{tabular}




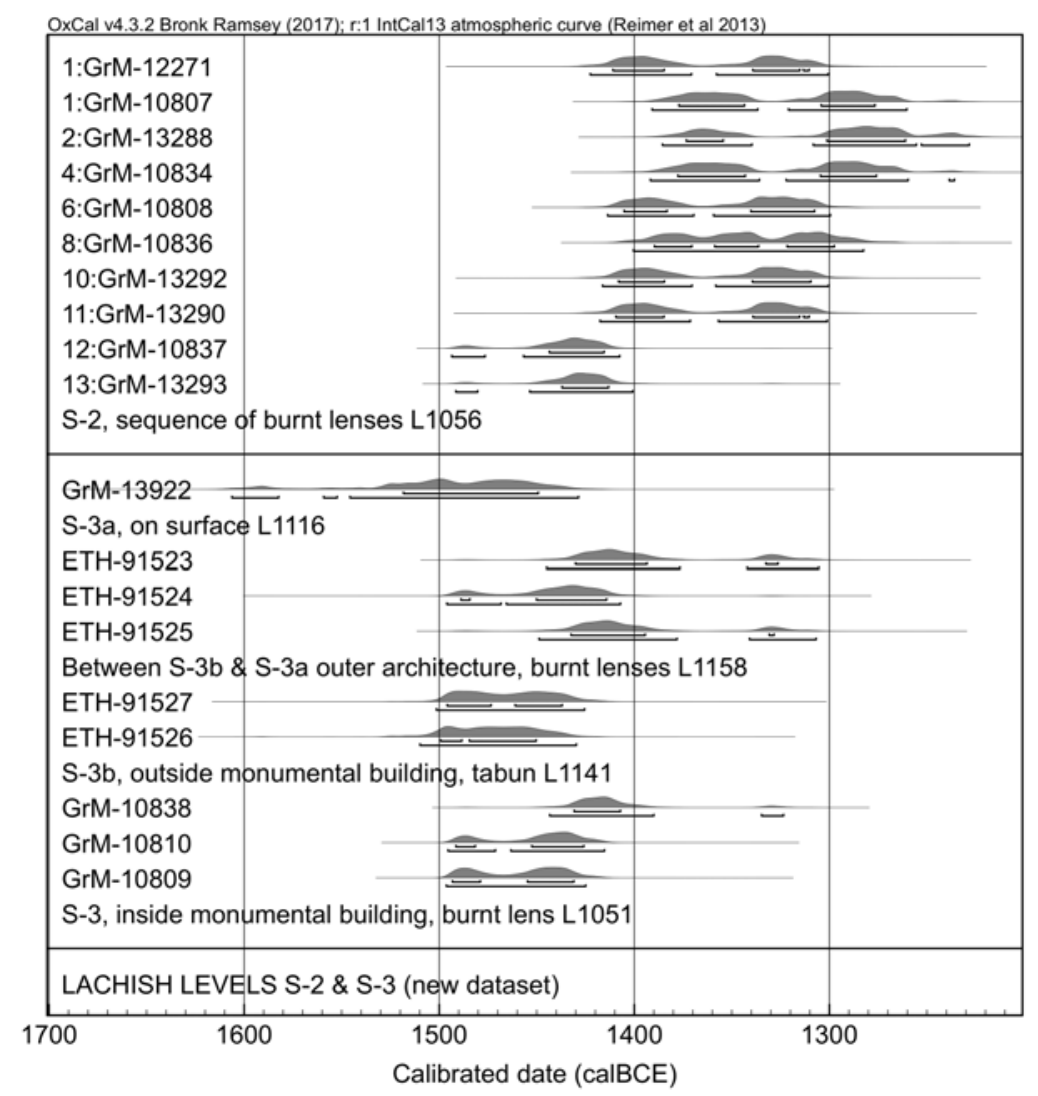

Figure 5 Independently calibrated new ${ }^{14} \mathrm{C}$ dates from Levels S-2 and S-3. (GrM11115 not shown.)

Beginning with Model A, the new S-3 data is arranged in two parallel phases, since the relative ordering of samples inside and outside the monumental building is difficult to know with certainty. From a single context inside the building are three new dates (L1051; GrM10809, 10810, and 10838). The sequence of dates from external architectural subphases consists of (from oldest to youngest): two dates from S-3b tabun L1141 (ETH-91526 and 91527), one date from each of three charred lenses that overlie the S-3b architecture (L1158; ETH-91525, 91524 and 91523), and one date from charred material lying directly on surface L1116 (lowest lens of L1056; GrM-13922). ${ }^{17}$

Eleven dates from burnt lenses within the laminated deposit of S-2 are arranged in stratigraphic sequence, above the S-3 phase. Regarding this dense sequence, we assume that the S-2 layers were not deposited rapidly but over a longer period, with different growing seasons represented in the organic material; this is supported by several observations: (1) depth of the deposit; (2) presence of similar charred layers between subphases of S-3 architecture; (3) evidence of ordering in the radiocarbon data before modeling.

\footnotetext{
${ }^{17}$ It is possible that GrM-13922 instead post-dates S-3a wall W1071, but moving this data point into the beginning of the S-2 phase has negligible effect on the models.
} 

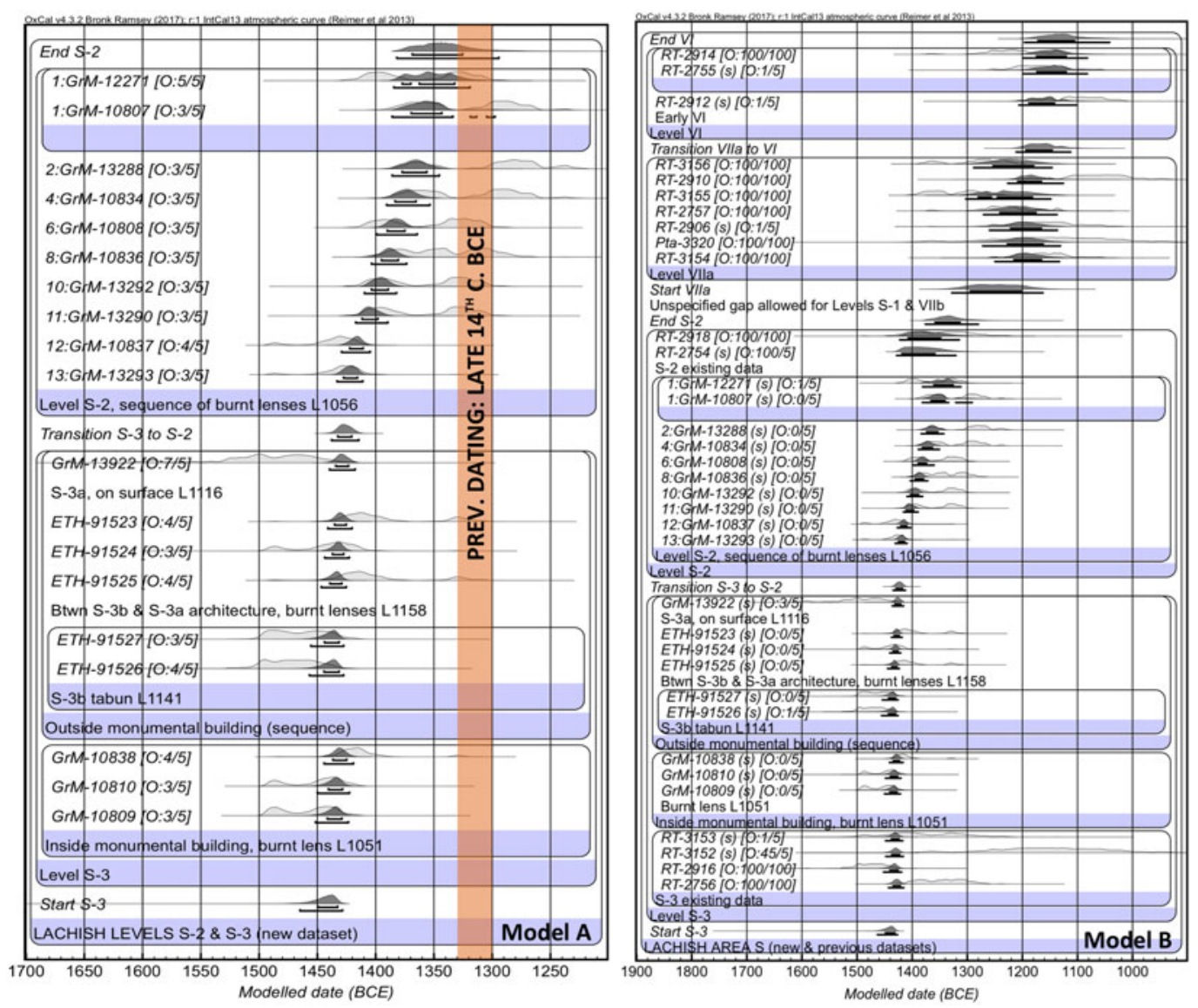

Figure 6 Bayesian analysis. Model A utilizes only new data for Levels S-2 and S-3. Model B incorporates existing data from all Late Bronze phases of Area S. In Model B, short-lived samples are denoted with “(s)”.

A contiguous boundary is assumed between the S-3 phase and S-2 sequence, as the archaeological evidence strongly indicates continuity. Outlier analysis is applied, such that the model can identify outliers and weight their influence accordingly, avoiding the need to manually remove them (Bronk Ramsey 2009b). An alternate approach to handling outliers, using agreement indices, gives similar results (see supplemental online materials Figure X2). ${ }^{18}$ In Model A all of the dates derive from short-lived materials; thus a "General" outlier distribution is assumed (Student's $t$ distribution) with prior outlier probabilities of $5 \%$.

Model A places Level S-3 and the transition to Level S-2 firmly within the second half of the 15th century BCE. Level S-2 continues through the first half of the 14th century BCE. It may be noted that before modeling many of the S-2 dates include probability extending into the late 14th and 13th centuries $\mathrm{BCE}$; this is due to wiggles in the ${ }^{14} \mathrm{C}$ calibration curve (refer Figure $\mathrm{X} 1$ ). However, when relative stratigraphic order is taken into account, it becomes clear that the

\footnotetext{
${ }^{18} \mathrm{An}$ agreement model leads to the exclusion of two dates with agreement indices $<60 \%$ : GrM-13922 and GrM-12271. The latter barely falls short, at 58\% agreement, and its removal leads to some additional probability for a later S-2 endpoint in the first half of the 13th century BCE. An outlier analysis that downweighs GrM-12271 rather than removing it seems more appropriate.
} 
S-2 deposit was laid down predominantly during the first half of the 14th century BCE. The last layers of S-2 were most likely deposited within the middle third of the century, but the late 14th century BCE remains a possibility.

Having considered the new data alone, we include an updated model for the LBA in Lachish Area S. Model B incorporates the existing data of Carmi and Ussishkin (2004). We prefer a single area model that does not include data from other excavation areas; thus the model is constrained only by prior information from stratigraphic order, and not ceramic parallels between areas. ${ }^{19}$ Carmi and Ussishkin's dataset includes four dates from S-3 and two from $\mathrm{S}-2$, which we arrange in phases parallel to the new data. Seven and three dates, respectively, represent later Levels VII and VI. A contiguous boundary is assumed between Levels VII and VI, but a non-contiguous boundary between S-2 and VII allows for the absence of data from S-1 and VIIb.

We have chosen to include both wood and short-lived dates of the Carmi and Ussishkin dataset. There are very few dates of the latter category ${ }^{20}$ and restricting the model to only short-lived samples would mean eliminating most of the previous dataset from consideration. As shown by Dee and Bronk Ramsey (2014) the wood data contains valuable information beyond merely a terminus post quem. Potential inbuilt age within the wood data is addressed by applying a "Charcoal Plus" outlier model; this assumes an outlier distribution exponentially approaching the true context age, while also allowing a small possibility that some wood charcoal may be intrusive. The wood dates are each given a $100 \%$ prior probability of being an outlier (i.e. having a biological age earlier than the context). ${ }^{21}$

Comparing Models A and B, it may be noted that the larger model does little to alter the results of Model A. The less precise previous data for Levels S-2 and S-3 have minimal influence and are broadly compatible (with the exception of clear outliers RT-2754 and RT-3152). The inclusion of data from Levels VIIa and VI has a minor downward effect on the end of S-2; in reverse, the new S-2 to S-3 dataset has a more perceptible effect on the Level VII data, yielding more probability in the 13th century BCE than seen in previous models (Webster et al. 2018).

Manning et al. (2018) recently published evidence for a small regional ${ }^{14} \mathrm{C}$ offset for the southern Levant, measured at $19 \pm 5$ years in tree records of the 17 th-19th centuries CE. A similar offset was found in Egypt by Dee et al. (2010, 2013a). ${ }^{22}$ We have considered the potential effect of an offset of this magnitude on the Lachish LBA data (refer to Figure X3) and note that it has limited impact. The conclusions for the dating of S-3 and S-2 remain the same; probability for a later continuation of S-2 is increased in Model B but $>80 \%$ probability remains within the 14 th century BCE.

\section{DISCUSSION}

The new ${ }^{14} \mathrm{C}$ data and Bayesian analysis place Lachish Level S-3 within the second half of the 15 th century BCE, and the commencement of Level S-2 before the close of that century. It is

\footnotetext{
${ }^{19}$ We have also considered a full site-wide model of LBA Lachish (including the data of Garfinkel et al. 2019a). This produces very similar results to the Area $\mathrm{S}$ model and will be presented elsewhere.

${ }^{20}$ Efforts to obtain new AMS ${ }^{14} \mathrm{C}$ dates from short-lived materials of Area S Levels VII and VI are ongoing.

${ }^{21}$ If the model is restricted to only short-lived dates, the results are nonetheless similar.

${ }^{22}$ Such regional offsets would have fluctuated over time but are by nature small; pending further data, their magnitude in earlier periods should not be estimated at more than 2-3 decades.
} 
therefore evident that the previous excavation in Area S reached a century further back into the LBA than was previously thought.

The redating of Level S-3 eliminates the occupation gap previously suggested at Lachish for the 2nd half of the 15th century BCE. With its monumental architecture, S-3 now constitutes evidence for a substantial, well-organized settlement at this time. In terms of Egyptian chronology, this corresponds to the reigns of Thutmoses III and Amenhotep II, leading to improved agreement with textual sources-notably the reference to Lachish in Papyrus Hermitage 1116A during the reign of Amenhotep II. ${ }^{23}$ Given the generally accepted dating of Fosse Temple I to this same period, S-3 may constitute the missing contemporaneous settlement.

The laminated deposit of Level S-2-evidence of intensive activity, and in our view of settlement on the mound-commenced in the late 15th century BCE and continued through the first half of the 14th century BCE. The lowest layers of the deposit probably predate Fosse Temple II (built during or after Amenhotep III). A starting date for S-2 prior to Amenhotep III is not contradicted by the seal of this king found in S-2 L3938 (Keel 2004, List no. 25), as it was retrieved from the upper layers of the deposit (Barkay and Ussishkin 2004:326, Figure 8.11). In fact when this evidence is combined with ${ }^{14} \mathrm{C}$, we see that S-2 must overlap Amenhotep III's reign (and probably also Fosse Temple II). Level S-2 seems to have ended in the middle third of the 14th century. It is difficult to more precisely establish this endpoint, or the beginning of the Level VII city, unless high quality dates from the directly overlying strata (S-1 and VIIb) can be obtained.

The impact of the new S-3-S-2 ${ }^{14} \mathrm{C}$ results on synchronization with Egyptian history is further discussed by Webster et al. (2019), using direct comparison with ${ }^{14} \mathrm{C}$ analysis for the absolute dating of the New Kingdom (Dee 2013b).

The current results should be viewed as a redating of specific strata rather than evidence for a wider adjustment to the absolute dating of cultural periods. The ceramic assemblages of S-3-S-1 were modest, consisting predominantly of sherd material with few restorable vessels (unlike the much larger whole vessel assemblages of Levels VII and VI). Furthermore, the inherent difficulties in differentiating LB IB and IIA pottery may be noted. Thus while Yannai placed S-1-3 in LB IIA, a reattribution of S-3 to LB IB should be considered. ${ }^{24}$ The presented results furthermore serve as an example of how ${ }^{14} \mathrm{C}$ dating can help to reassess $\mathrm{LB}$ I occupation gaps, which have been exaggerated in some cases through an overreliance on imported fossil directeur pottery types (e.g. Bourke 1993:166-167; Duff 2015:62-70).

Few ${ }^{14} \mathrm{C}$ datasets have been published from LB IB-IIA strata of southern Levantine sites. This portion of the important Megiddo sequence is under-represented; however it may be said that Stratum F-10 is likely contemporary with Lachish Level S-3, and Stratum K-9 with Level S-2 (Toffolo et al. 2014). ${ }^{25}$ Closer to Lachish, recent excavation and ${ }^{14} \mathrm{C}$ work at Tel Azekah is also augmenting our picture of the Shephelah during the Amarna period, indicating the presence of a thriving town with public architecture (Webster et al. 2018; forthcoming).

\footnotetext{
${ }^{23}$ The accession of Thutmoses III is dated 1499-1472 BCE (95\% probability; Dee 2013b, NKM1 with reign lengths in Shaw 2000). Amenhotep II: 1446-1421 BCE.

${ }^{24}$ While a detailed review of the local and imported S-1-3 pottery is pending, the earlier dating can probably be accommodated (personal communication, Eli Yannai).

${ }^{25}$ It is unclear which phase/s of Area K may correspond to Lachish Level S-3. Toffolo et al. (2014:241) suggest a short gap in Area K during the late LB I.
} 


\section{CONCLUSION}

Our ${ }^{14} \mathrm{C}$-based reassessment in Lachish Area S, using a new suite of well-stratified samples from secure contexts, shows that the date of Level S-3 and the commencement of Level S-2 should be raised by a century. Consequently these levels now furnish evidence of a prominent, wellorganized settlement at Lachish during the 2 nd half of the 15 th century BCE, as well as an indication of continued settlement through the Amarna period in the 14th century BCE. Noting the improved agreement with textual evidence for Lachish's prominence and interaction with the Egyptian administration during LB IB-IIA, this outcome highlights the important role of ${ }^{14} \mathrm{C}$ for correctly synchronizing southern Levantine strata with Egyptian history.

\section{ACKNOWLEDGMENTS}

This research was funded by Austrian Science Fund (FWF) START grant Y-932, "Tracing transformations in the southern Levant: from collapse to consolidation in the mid-second millennium BC," directed by Dr Felix Höflmayer. The work forms part of the leading author's PhD research. The authors would like to thank the excavation staff of the AustrianIsraeli Expedition to Tel Lachish, and the laboratory teams at the University of Groningen and ETH Zurich AMS facilities. We are grateful to Dr Mans Schepers for botanical identifications made at the University of Groningen's archaeobotany laboratory; further identifications were made by Marco Nicoli (Tübingen University). Insightful comments offered by Stephen Bourke and Yuval Gadot on the manuscript are gratefully acknowledged.

\section{SUPPLEMENTARY MATERIAL}

To view supplementary material for this article, please visit https://doi.org/10.1017/RDC. 2019.131

\section{REFERENCES}

Albright WF. 1944. A prince of Taanach in the fifteenth century BC. Bulletin of the American Schools of Oriental Research 94:12-27.

Barkay G, Ussishkin D. 2004. Area S: The Late Bronze Age strata. In: Ussishkin D, editor. The renewed archaeological excavations at Lachish (1973-1994). Volume I. Tel Aviv: Institute of Archaeology of Tel Aviv University. p. 316-410.

Bietak M. 2002. The function and some architectural roots of the Fosse Temple at Lachish. In: Ahituv $\mathrm{S}$, Oren ED, editors. Aharon Kempinski Memorial Volume: Studies in archaeology and related disciplines. Beer Sheva: Ben Gurion University of the Negev Press. p. 56-85.

Bliss FJ. 1894. A mound of many cities. Tell El Hesy excavated. London: Macmillan.

Bronk Ramsey C. 2009a. Bayesian analysis of radiocarbon dates. Radiocarbon 51(1):337-360.

Bronk Ramsey C. 2009b. Dealing with outliers and offsets in radiocarbon dating. Radiocarbon 51(3):1023-1045.

Bronk Ramsey C, Dee MW, Rowland, JM, Higham TF, Harris SA, Brock F, Quiles A, Wild EM,
Marcus ES, Shortland AJ. 2010. Radiocarbonbased chronology for dynastic Egypt. Science 328:1554-1557.

Bourke SJ. 1993. The transition from the Middle to the Late Bronze Age in Syria: the evidence from Tell Nebi Mend. Levant 25:155-195.

Buck CE, Kenworthy JB, Litton CD, Smith AFM. 1991. Combining archaeological and radiocarbon information: a Bayesian approach to calibration. Antiquity 65(249):808-821.

Buck CE, Litton CD, Smith AFM. 1992. Calibration of radiocarbon results pertaining to related archaeological events. Journal of Archaeological Science 19(5):497-512.

Carmi I, Ussishkin D. 2004. ${ }^{14} \mathrm{C}$ dates. In: Ussishkin $\mathrm{D}$, editor. The renewed archaeological excavations at Lachish (1973-1994). Volume V. Tel Aviv: Institute of Archaeology of Tel Aviv University. p 2508-2513.

Clamer C. 2004. Additional Late Bronze Age pottery assembages. Section A: The pottery from levels P2 and P-1 in Area P. In: Ussishkin D, editor. The renewed archaeological excavations at Lachish 
(1973-1994). Volume III. Tel Aviv: Institute of Archaeology of Tel Aviv University. p 11551234.

Dee MW. 2013a. Investigating the accuracy of radiocarbon dating in Egypt: checks with samples of known age. In: Shortland AJ, Bronk Ramsey C, editors. Radiocarbon and the Chronologies of Ancient Egypt. Oxford: Oxbow Books. p. 53-64.

Dee MW. 2013b. A radiocarbon-based chronology for the New Kingdom. In: Shortland AJ, Bronk Ramsey C, editors. Radiocarbon and the chronologies of Ancient Egypt. Oxford: Oxbow Books. p. 65-75.

Dee MW, Brock F, Harris SA, Bronk Ramsey C, Shortland AJ, Higham TF, Rowland JM. 2010. Investigating the likelihood of a reservoir offset in the radiocarbon record for ancient Egypt. Journal of Archaeological Science 37(4):687-93.

Dee MW, Bronk Ramsey C. 2014. High-precision Bayesian modeling of samples susceptible to inbuilt age. Radiocarbon 56(1):83-94.

Dever WG. 1986. Gezer IV: the 1969-1971 Seasons in Field VI, the "Acropolis." Jerusalem: Annual of the Nelson Glueck School of Biblical Archaeology.

Duff CA. 2015. Shechem V: The Late Bronze Age pottery from Field XIII at Shechem/Tell Balatah. Boston: American Schools of Oriental Research.

Epstein C. 1963. A new appraisal of some lines from a long-known papyrus. The Journal of Egyptian Archaeology 49(1):49-56.

Finkelstein I. 1988. The archaeology of the Israelite Settlement. Jerusalem: Israel Exploration Society.

Finkelstein I. 1996. The territorial-political system of Canaan in the Late Bronze Age. UgaritForschungen 28:221-255.

Gadot Y. 2009. Iron Age (Strata X11-X6). In: Gadot Y, Yadin E, editors. Aphek-Antipatris II. Tel Aviv: Institute of Archaeology of Tel Aviv University. p. 88-108.

Garfinkel Y, Hasel MG, Klingbeil MG, Kang H-G, Choi G, Chang S-Y, Hong S, Ganor S, Kreimerman I, Bronk Ramsey C. 2019a. Lachish fortifications and state formation in the biblical kingdom of Judah in light of radiometric datings. Radiocarbon 61(3):695-712.

Garfinkel Y, Kreimerman I, Hasel MG, Klingbeil MG. 2019b. First impression on the urban layout of the last Canaanite city of Lachish: A view from the northeast corner of the site. In: Maeir AM, Shai I, McKinny C, editors. The Late Bronze and Early Iron Ages of Southern Canaan. Berlin: De Gruyter. p. 122-135.

Golénischeff W, ed. 1913. Les Papyrus Hiératiques Nos. 1115, 1116A, Et 1116B De l'Ermitage Impériale a St. Petersbourg. St. Petersburg: Manufacture Des Papiers De L'état.
Goren Y, Finkelstein I, Na'aman N. 2004. Inscribed in Clay. Tel Aviv: Institute of Archaeology of Tel Aviv University.

Helck W. 1971. Die Beziehungen Ägyptens Zu Vorderasien im 3. und. 2. Jahrtausend v. Chr. 2nd edition. Wiesbaden: Harrassowitz.

Horowitz W, Oshima T, Sanders SL. 2006. Cuneiform in Canaan: Cuneiform sources from the land of Israel in ancient Times. Jerusalem: Israel Exploration Society.

Keel O. 2004. Scarabs, stamp seal-amulets and impressions. In: Ussishkin D, editor. The renewed archaeological excavations at Lachish (1973-1994). Vol. III. Tel Aviv: Institute of Archaeology of Tel Aviv University. p. 1537-1571.

Koch I. 2017. Revisiting the Fosse Temple at Tel Lachish. Journal of Ancient Near Eastern Religions 17:64-75.

Malamat A. 1961. Campaigns of Amenhotep II and Thutmose IV to Canaan. Scripta Hierosolymitana 8:218-231.

Manning SW, Griggs C, Lorentzen B, Bronk Ramsey C, Chivall D, Jull AT, Lange TE. 2018. Fluctuating radiocarbon offsets observed in the southern Levant and implications for archaeological chronology debates. Proceedings of the National Academy of Sciences of the United States of America:201719420.

Martin MAS. 2011. Egyptian-type pottery in the Late Bronze Age Southern Levant. Vienna: Österreichische Akademie Der Wissenschaften.

Millard AR. 2014. Conventions for reporting radiocarbon determinations. Radiocarbon 56(2):555-559.

Mook WG, Streurman HJ. 1983. Physical and chemical aspects of radiocarbon dating. In: Mook WG, Waterbolk HT, editors. ${ }^{14} \mathrm{C}$ and archaeology. Strasbourg: Council of Europe. p. 31-54.

Moran WL. 1992. The Amarna letters. Baltimore: Johns Hopkins University Press.

Na'aman N. 1997. The network of Canaanite late Bronze kingdoms and the city of Ashdod. Ugarit-Forschungen 29:599-626.

Na'aman N. 2011. The Shephelah according to the Amarna Letters. In: Finkelstein I, Na'aman N, editors. The Fire Signals of Lachish. Winona Lake: Eisenbrauns. p. 281-99.

Panitz-Cohen N. 2014. The southern Levant (Cisjordan) during the Late Bronze Age. In: Steiner ML, Killebrew AE, editors. The Oxford Handbook of the Archaeology of the Levant c. 8000-332 BCE. Oxford: Oxford University Press. p. $541-560$.

Petrie WMF. 1981. Tell El Hesy (Lachish). London: Palestine Exploration Fund.

Rainey, AF. 2015. The El-Amarna correspondence: A new edition of the cuneiform letters from the site of El-Amarna based on collations of all extant tablets. Leiden: Brill. 
Redford DB. 1965. The coregency of Tuthmosis III and Amenophis II. The Journal of Egyptian Archaeology 51(1):107-122.

Reimer PJ, Bard E, Bayliss A, Beck JW, Blackwell PG, Bronk Ramsey C, Buck CE, Cheng H, Edwards RL, Friedrich M, Grootes PM, Guilderson TP. 2013. IntCal13 and Marine13 radiocarbon age calibration curves $0-50,000$ years cal BP. Radiocarbon 55(4):1869-1887.

Sala M, Tucci G. 2019. Egyptian worshippers in Canaanite sanctuaries: cultural negotiation in temples and paraphernalia from the LB IIB-IA IA Southern Levant. Journal of Ancient Egyptian Interconnections 21:48-67.

Sass B, Garfinkel Y, Hasel MG, Klingbeil MG. 2015. The Lachish jar sherd: an early alphabetic inscription discovered in 2014. Bulletin of the American Schools of Oriental Research 374:233-245.

Shahack-Gross R, Gafri M, Finkelstein I. 2013. Identifying threshing floors in the archaeological record: a test case at Iron Age Tel Megiddo, Israel. Journal of Field Archaeology 34(2):171-184.

Shaw I, editor. 2000. The Oxford history of ancient Egypt. Oxford: Oxford University Press.

Singer-Avitz L. 2004a. The pottery of the Late Bronze I phase. Section A: The Area P assemblage. In: Ussishkin D, editor. The renewed archaeological excavations at Lachish (1973-1994). Volume III. Tel Aviv: Institute of Archaeology of Tel Aviv University. p. 1012-1022.

Singer-Avitz L. 2004b. The pottery of the Late Bronze I phase. Section B: The Cypriot Bichrome Ware. In: Ussishkin D, editor. The renewed archaeological excavations at Lachish (19731994). Volume III. Tel Aviv: Institute of Archaeology of Tel Aviv University. p 1023-1031.

Streit K. 2019. Archaeological evidence for the presence of Egyptians in the southern Levant during the Late Bronze Age - a reappraisal. Journal of Ancient Egyptian Interconnections 21:68-87.

Streit K, Webster L, Becker V, Jeske A, Misgav H, Höflmayer F. 2018. Between destruction and diplomacy in Canaan: the Austrian-Israeli expedition to Tel Lachish. Near Eastern Archaeology 81(4):259-268.

Stuiver M, Polach HA. 1977. Discussion: reporting of ${ }^{14} \mathrm{C}$ data. Radiocarbon 19(3):355-363.

Toffolo MB, Arie E, Martin MAS, Boaretto E, Finkelstein I. 2014. Absolute chronology of Megiddo, Israel, in the Late Bronze and Iron Ages: high-resolution radiocarbon dating. Radiocarbon 56(1):221-244.
Tufnell O. 1958. Lachish IV: the Bronze Age. London: Oxford University Press.

Tufnell O, Inge CH, Harding L. 1940. Lachish II: the Fosse Temple. London: Oxford University Press.

Ussishkin D. 2004a. A synopsis of the stratigraphical, chronological and historical issues. In: Ussishkin D, editor. The renewed archaeological excavations at Lachish (1973-1994). Volume I. Tel Aviv: Institute of Archaeology of Tel Aviv University. p. 50-119.

Ussishkin D. 2004b. The mound and excavation strategy. In: Ussishkin D, editor. The renewed archaeological excavations at Lachish (19731994). Volume I. Tel Aviv: Institute of Archaeology of Tel Aviv University. p. 23-49.

Ussishkin D. 2004c. Area P: the Late Bronze Age strata. In: Ussishkin D, editor The renewed archaeological excavations at Lachish (19731994). Volume I. Tel Aviv: Institute of Archaeology of Tel Aviv University. p. 188-214.

Ussishkin D. 2004d. Area D: the Bronze Age strata. In: Ussishkin D, editor. The renewed archaeological excavations at Lachish (19731994). Volume I. Tel Aviv: Institute of Archaeology of Tel Aviv University. p. 282-315.

Ussishkin D. 2004e. Area GE: the inner city-gate. In: Ussishkin D, editor. The renewed archaeological excavations at Lachish (1973-1994). Volume II. Tel Aviv: Institute of Archaeology of Tel Aviv University. p. 624-689.

Webster LC, Sergi O, Kleiman S, Lipschits O, Hua Q, Jacobsen GE, Tristant Y, Gadot Y. 2018. Preliminary radiocarbon results for Late Bronze Age strata at Tel Azekah and their Implications. Radiocarbon 60(1):309-331.

Webster L, Streit K, Dee MW, Hajdas I, Höflmayer F. 2019. Identifying the Lachish of Papyrus Hermitage 1116A Verso and the Amarna Letters: implications of new radiocarbon dating. Journal of Ancient Egyptian Interconnections 21:88-99.

Weissbein I, Garfinkel Y, Hasel MG, Klingbeil MG. 2016. Goddesses from Canaanite Lachish. Strata: Bulletin of the Anglo-Israel Archaeological Society 34:41-55.

Wild EM, Steier P, Fischer PM and Höflmayer F. 2013. ${ }^{14} \mathrm{C}$ dating of humic acids from Bronze and Iron Age plant remains from the Eastern Mediterranean. Radiocarbon 55(2-3):599-607.

Yannai E. 2004. The Late Bronze Age pottery from Area S. In: Ussishkin D, editor. The renewed archaeological excavations at Lachish (19731994). Volume III. Tel Aviv: Institute of Archaeology of Tel Aviv University. p. 1032-1146. 